\title{
Understanding the role the Bible Society of South Africa played in the development of missions in South Africa ${ }^{1}$
}

F Sieberhagen $^{2}$

(University of Pretoria)

\section{ABSTRACT}

\section{Understanding the role the Bible Society of South Africa played in the development of missions in South Africa}

This article argues that the development of Missions in South Africa could be directly linked to the founding of Bible Society work in South Africa. The article focuses on the development of missions and how the availability of Scriptures in the vernacular enhanced this work. The unique relationship between Mission development, the Church and the Bible Society will be discussed as to highlight and fully understand this unique influence and partnership. This partnership is an ongoing relationship and with the new challenges arising this will have to be developed even further.

\section{INTRODUCTION}

Since it seems that the Bible Society of South Africa has been there "forever", the question should be asked if the Bible Society played a significant role in the missionary activity in South Africa. Did the Bible Society play a role in the Christianising of South Africa, and has it received or deserved any recognition for this role?

One can only assume that there must have been an intertwined relationship between the Bible Society of South Africa and the development of the missionary activities in South Africa, especially after 1820, the year in which the Bible Society activities started. On the one hand there was the need for printed Bibles in the vernacular, and on the other hand there was the need to transform the oral

1 This article is based on his doctoral thesis in missiology at UP, which was completed in 2000. It was entitled: "The publication, by the Bible Society of South Africa, of the Bible in the indigenous languages of South Africa - a Missiological study" (Sieberhagen 2000). His promoter was Prof J J (Dons) Kritzinger. Dr Sieberhagen can be contacted at francois@ubssarsc.org.za

2 Dr Francois Sieberhagen is currently working for the United Bible Societies as a Media Consultant and is based at the Regional Service Centre in Kempton Park. 
languages into a written format as to be able to translate the Bible. There was therefore the immense role that missionaries played as pioneer translators of the Bible in vernacular and the Bible Society in coordinating and publishing these works.

This article is meant to open the window on the work that the Bible Society of South Africa - future references will only be to Bible Society - has done to provide affordable biblical material in the vernacular, and that without any dogmatic notes or comments for use by all Churches and Missionary organisations in their quest to spread the Gospel. This material included Bibles, New Testaments, Scripture Portions, Scripture Selections, New Reader Portions and Selections, Audiocassettes with Scripture recordings, as well as Braille Bibles.

To understand the immense work that has been done throughout the years it will be good to understand the position that the Bible Society has taken in its relationship with the Church as a whole, its history in the light of the development of Missions in South Africa and eventually to understand and appreciate the cooperative relationship.

\section{MISSIONARY ACTIVITIES IN SOUTH AFRICA}

With a population of roughly 40 million, just over $73 \%$ of the South African population describe themselves as Christians. So there must have been some success in the past. The question arises: was it the preaching of the Gospel alone, did the encounter with the printed Bible also play a role in the life changing experience that the people of South Africa experienced? This question in itself will need some separate deliberation, but to understand and appreciate the development of Christianity in South Africa it will be necessary to give a brief overview concerning the missionary activities.

David Bosch (1991:389) makes the following statement, which provides an acceptable start to the intended overview. He writes in his book Transforming Mission:

"During the past half a century or so there has been a subtle but nevertheless decisive shift towards understanding mission as Gods mission. During preceding centuries mission was understood in a variety of ways. Sometimes it was interpreted primarily in soteriological terms: as saving individuals from eternal 
damnation. Or it was understood in cultural terms: as introducing people from the East and the South to the blessings and privileges of the Christian West. Often it was perceived in ecclesiastical categories: as the expansion of the church (or a specific denomination). Sometimes it was defined salvation-historically: as the process by which the world - evolutionary or by means of a cataclysmic event - would be transformed into the kingdom of God".

The assumption can be made that in South Africa these above mentioned paradigms have been present throughout the years. Missions did develop along those lines.

Charles van Engen (1996:20) describes these different paradigms in Missions in other terms, but just as relevant to the situation in South Africa when he writes:

"Missiologists have differed in the integrating idea or phrase they have chosen to use as the center of their missiology. Examples of integrating ideas would include the conversion of the heathen, the planting of the church and the glory of God (Gijsbert Voetius), the Great Commission (William Carey), the lostness of humanity (Pietism), the praise of God (Orthodox missiology), the people of God (Vatican II), making disciples of panta ta ethne (Donald McGavran), the God of history, God of compassion, God of Transformation (David Bosch), the kingdom of God (Arthur Glasser), and humanization (the World Council of Churches). Among other integrating concepts is the pain of God, the cross, bearing witness in six continents, ecumenical unity, the covenant, and liberation".

Bosch (1991:512) also says that mission is a multifaceted ministry in respect of witness, service, justice, healing, reconciliation, liberation, peace, evangelism, fellowship, church planting, contextualisation, and much more. Did the Bible Society play a role in influencing these different ministries?

When did it all start in South Africa, and who were the major role players in the mission fields of South Africa? Did the availability of Scriptures enhance the missionary activities in South Africa? 
To shed some light on these questions the involvement of three of the major role players will be discussed briefly.

\subsection{Mission - the task of the Church}

Undoubtedly the Church has been and had to be the major role player in the Mission field. Verkuyl, in his book Contemporary Missiology (1978:27) discusses the history of the mission development, and quotes Gustav Warneck concerning the development of missions, and the role the Church has played. $\mathrm{He}$ writes: "Only the Christian religion has a church, [and] to her belongs the inherent task of world mission. The church is 'the institute of healing [Heilsanstalt] for all humanity'. But '...she must engage in mission for her own sake [as well]. From it she exists; if she was to give it up, she would be cutting off her own lifeline'. Through missionaries, and the churches which they establish, the 'Christianising of nations' takes place".

Indeed the Christianising of the different peoples in South Africa has taken place "successfully", as has been indicated by the official statistics of the Government.

This "Christianising of nations" also has got another dimension. Andrew Walls (1996:86) points out that the Christian mission is not simply about the multiplication of the church, but it is about the discipling of the nations. To him it means that cultures and ways of thought should be penetrated by the word of Christ. It is the translation of Scripture into thought and action, when the word of Christ is brought to bear on the points of reference within each culture, the things by which people know themselves and recognise where they belong.

Although we can say that the Church has more than played its positive part, there is also room for criticism concerning the negative "penetration of cultures". Walls and others describe the devastating effect this process had on the survival of the indigenous cultures in South Africa, and how the enculturation of the local Churches has been hampered.

Stephen Neill (1964:249) is even more critical when he says:

"It is to be remembered that in the nineteenth century the alternatives for many peoples were not independence and enslavement but total destruction (by unscrupulous 
exploiters or through the slave-trade) and the possibility of survival in a state of colonial dependence".

Nico Smith, a South African Missiologist supports this criticism when he quotes McGavran that describes this destruction by saying: "Missions were carried on from the ruling, wealthy, literate, modern countries, which were experiencing all the benefits of ... an expanding production, and universal education". This has lead to "separateness" between missions and the indigenous people (Smith 1980:142).

Not withstanding the justified criticism it has to be acknowledged that the church has and is still playing its role in the mission fields of South Africa in endeavouring to reach all the people with the gospel.

\subsection{Mission - the task of Mission Societies}

It is clear that the relationship between church and mission societies was not always as close as it was suppose to be. Missions were not necessarily a high priority and have not been practised as much as could have been expected.

For many years the church left it to the missionary organisations to do missions on their behalf. These Missionary organisations in question have largely been the result of the Revivals in England and America during the late eighteenth and early nineteenth century.

Concerning the work of these Missionary organisations Smith says: "Not the church as the mystical body of Christ to which all believers belong, but a "society" of believers which should be saved from the world, was central to the purpose of these missionary societies" (Smith 1980:188,192).

Notwithstanding this and other negative remarks the work that has been done should receive recognition. Many Societies worked in South Africa, with different levels of involvement as well as success. Some of these were the Moravian Missionary Society, from as far back as 1737, the London Missionary Society and South African Missionary Society started in 1799, the Wesleyan Methodist Missionary Society in 1816, the Scottish or Glasgow Missionary Society in 1824, the Paris Evangelical Missionary Society and the Rhenish Missionary Society both since 1829, the Berlin Missionary Society in 1834 . Further societies which could be mentioned are: the 
Hermannsburg Missionary Society and the American Board of Commissioners for Foreign Missions since 1834, the Church Missionary Society since the 1830's, the Norwegian Missionary Society in 1844, the Swedish Missionary Society and the Swiss Missionary Society.

The single biggest critique that can be brought against these Societies is the fact that they existed alongside the Church. Often where they planted churches they were never inculturised or contextualised.

Stephen Neill has made the following relevant observation:

"All unnoticed, the mission had slipped into the position of the church. Many missionaries went out with the best intentions of carrying out the declared intention of the London Missionary Society to preach the pure Gospel without tying it to any western form of organisation or policy, but they usually ended by producing a copy, faithful down to the minutest detail, of that form of the Christian faith to which they themselves were accustomed in their own country" (Neill 1964:259).

This indeed happened in South Africa in the early years, although of late there is a definite movement toward contextualising these Churches.

\subsection{Mission - The task of the Bible Societies}

One has to be very clear in understanding the role of the Bible Society, not get confused, or assign the wrong role to it. The Missionary Societies and Bible Societies share the same "surname": Society. As not to be confused it will be good to understand the similarities as well as differences.

Both these organisations have succeeded in bringing together Christians from different confessional backgrounds into one organisation and raise support for the work that they were doing.

However the critical difference between the Bible Societies and the Missionary Societies is that the latter were focusing on evangelising people, while the Bible Societies were (only) focusing on translating the Bible in vernacular, without any dogmatic comment or additional notes and to make it available at a price people could afford. 
It is therefore clear that, the Bible Society, although a Society is neither a Missionary Society nor Church, and does not want to be either of these. It has a unique and focused mission and vision, and as pointed out by Tolmie (1997): "The Bible Society's sole objective is to promote a wider effective distribution of the Holy Scriptures in close liaison with all church denominations".

What is important to realise is that the Evangelical revivals, which had such an important influence on the establishment of Missionary Societies also impacted the Bible Societies.

"Basically the Evangelical Revival was a return to the Bible, or at least it was accompanied by such a return, in much the same way as the Reformation was accompanied by a rediscovery of the Bible. In the years immediately before the Revival the Bible had not been suppressed, it had merely been neglected. It was a book that few read and fewer acted upon (Chirgwin 1954:43).

This newfound enthusiasm for the Bible and Bible use spilled over and led to the acceleration of mission development in South Africa and elsewhere.

Bible Societies came into being, without which the missions would have been greatly handicapped. In time each of the Protestant countries of the world organised its own Bible Society. Especially four of these Bible societies have made an enormous contribution to Christian missions around the world: the British and Foreign Bible Society (1804), the National Bible Society of Scotland (1809), Netherlands Bible Society (1814), and the American Bible Society (1816) (Kane 1978:95).

Eric Fenn (Fenn, in Greenslade 1963:388) underlines the influence that has gone out from the forming of the British and Foreign Bible Society, one of the first "bigger" Societies when he says:

"The foundation of the British and Foreign Bible Society at a meeting in the London Tavern, Bishopgate, on 7 March 1804, was more than the beginning of a national institution: it was the birth of a world-wide movement of Bible translation, printing and distribution which was destined to draw into its orbit men and women of many 
different nations and languages and of most, if not all, Christian traditions".

The fruits that this and other Bible Societies bore were truly beneficial to the missionary activities in South Africa throughout the years, and have influenced positively the lives of many of our nation's people.

Before the work in printed format of the Bible Society is discussed it will be enlightening to understand how the Bible Society perceives itself and its relationship with the Church and missionary organisations.

\section{WHO IS THE BIBLE SOCIETY OF SOUTH AFRICA?}

This seems to be a relevant question to ask when trying to understand the work that has been done by this Society. Before exploring the history of this Society it will be good to understand how they as a Society perceive themselves.

Dr Donald Tolmie (1997), the previous General Secretary of the Bible Society of South Africa, was quite clear on this description when he delivered a paper at the Africa Assembly of the United Bible Societies (A World Fellowship of Bible Societies) in Midrand in 1997. The paper was on the relationship between Church and Bible Society.

His line of reasoning, which is very much in line with the standpoint of the United Bible Societies (UBS), and which was affirmed by speakers at the World Assemblies in Chiang Mai (1980) and Budapest (1988), was that the Bible Society is neither Church nor para-Church or Missionary Organisation. It is the sole task of the Bible Society to supply the Church and Missionary Organisations with the one article they need to do their work, and that is the Bible in the different languages (vernacular) and appropriate formats that can be used, and at affordable prices.

Tolmie summarised this unique relationship when he said:

"The Christian Church is committed to teaching Scripture

in the language of the people (vernacular). The Bible Society is committed to providing Scripture in the languages of the people”.

Concerning the provision of the Bible in the languages of the people, the involvement of the Church is of paramount importance to the 
Bible Society. Firstly, although the Bible Society has the technical expertise to publish Bibles, it depends on the Church to support this effort financially through voluntary contributions.

Furthermore it is important to understand that the Bible Society does not translate the Bible in a vacuum. The Bible Society will not embark on a translation project unless asked to do so by a church active in the area where the language is spoken. These churches will also be approached to support this venture by providing capable linguists who could be seconded to help in this vital co-operative function.

\section{HISTORY OF THE BIBLE SOCIETY - A BRIEF OVER- VIEW}

The Naval Commissioner, Sir Jahleel Brenton, had a passion for Bible distribution. This led to the founding of the second Auxiliary of the British and Foreign Bible Society in Africa, 23 ${ }^{\text {rd }}$ August 1820. The meeting took place under the auspices of the then Lieutenant Governor of the Cape Colony, Sir Rufane Donkin. The young and small Auxiliary made a good start and showed much promise for the future (Smit 1970:14).

Unfortunately, as has happened elsewhere, this Auxiliary's work started to dwindle and eventually it merely existed on paper. On the $26^{\text {th }}$ July 1846 , under the guidance of T J Bourne, the South African Auxiliary received a new lease of life. The Auxiliary started to function again and kept up with the demand for Scriptures and went from strength to strength.

During April 1961 the name of the South African Auxiliary was changed to: The Bible Society of South Africa, an Auxiliary of the British and Foreign Bible Society. This name was short lived and on the $1^{\text {st }}$ November 1965 the name was changed once more, this time to The Bible Society of South Africa. The Bible Society has "gained" its independence from the British and Foreign Bible Society and could take its place as an independent Bible Society in the ranks of the United Bible Societies (UBS), which is a world fellowship of Bible Societies. Since that time until today they have been contributing to the World Service Programme of the UBS while other Societies in Africa receive funding from that programme. 
The Bible Society as an organisation is unique in the sense that it is neither Church nor a non-Governmental organisation, but its activities are being regulated by an Act of the South African Parliament. Act 15 of 1970 structures the activities of the Bible Society and the Bible Society. It still adheres to the requirements of this Act in the way they conduct their business.

Throughout the years the Bible Society has taken its mission and mission statement very seriously. This mission statement reads as follows: a Bible for every person in its own language (mother tongue) without any dogmatic note or comment, in appropriate formats that can be used at an affordable price. With this mission in mind it can be argued that the Bible Society has played an influential and dynamic role in the development and growth of Christianity in South Africa. This was done primarily through the effort of providing Scriptures and other material in vernacular.

\section{THE PRINTED WORD}

Kane (1978:95-96) describes the role of Bible Societies in making the printed word available as follows:

"Never before in the history of the world have so many organisations been dedicated solely to the translation, publication, and distribution of one book. Through the years they have worked very closely with various missions, regardless of their ecclesiastical affiliation, their theological orientation, or their geographical location. Actually the Bible societies are responsible only for the publication of Scriptures.

The translation work is done by missionaries, with advice and supervision of the Bible Society's linguistic experts. When it comes to distribution, the Bible Societies depend quite heavily on the missionaries at the local level".

The reason why the printed word in vernacular was necessary is obvious and do not need argumentation, but Kane (1975:68) formulated this obviousness as follows:

"The missionary's chief task is to share Jesus Christ with the non-Christian world. All he knows about Christ he learned from the Bible. Therefore it behoves him to have a thorough working knowledge of the Scriptures, which is able to make men wise unto salvation (2 Tim 3:1)". 
This working knowledge and "to be wise unto salvation," means practically that the Bible had to be accessible, not only to the Missionary but also to the people who has to be reached. It is therefore imperative that the work in vernacular had to progress at a rate that would make this noble goal reachable.

Translation work in South Africa has followed a long and tedious route as to enable the Bible Society to claim that they have translated and published the Bible in 10 of the 11 official languages. Currently they are working on translating the Southern Ndebele Old Testament and Afrikaans Bible for the Deaf.

Of this long and tedious route Hermanson (1999:3) wrote:

"In preparation for their work, missionaries studied Hebrew, Greek and Latin. Translation theory was not well developed and so when they came to translate they did so with formal equivalence, in the same way as they had been taught to translate the Classics, matching word for word and structure for structure wherever possible".

Out of the publications and files of the Bible Society I will only highlight the first translations. Because of the lack of space no attention will be given to revisions, since all of these first translations have been revised or completely new translations have been done ${ }^{3}$.

Tswana - In 1830 the first Gospel, Luke was produced by Robert Moffat and printed in South Africa. In 1840 the New Testament was published, in 1853 the first half of the Old Testament (Genesis -2 Kings), and in 1857 the rest of the Old Testament. The complete Bible was first published as a unity in 1872. During 1970 the Setswana Bible, specifically translated for the South African Tswana speakers, was published for the first time.

Xhosa (isiXhosa) - In 1833 the first translation of the Gospel according to Luke was published. It was only in 1846 that the complete New Testament was published. In 1859 the Old Testament

3 The books of G E Coldham, A Bibliography of Scriptures in African Languages as well as Darlow, M A and M A Moule (eds), Historical Catalogue of the Printed Editions of Holy Scripture in the Library of the British and Foreign Bible Society and the unpublished work of J L Reyneke are quoted. 
was published and therefore a complete translation of the Bible was available.

Southern-Sotho (Sesotho) - In 1839 the Gospels of Mark and John was published. During 1855 the New Testament became available and in 1881 the complete Bible was published for the first time.

Zulu (isiZulu) - During 1846 the first selection, namely Genesis, was printed. The Gospel of Matthew was published in 1848 and the New Testament during 1865. The complete Bible was first published in 1883 .

Tsonga (Xitsonga) - As far back as 1883 a selection was published, and in 1892 the Gospel of Luke and the book of Acts was published. In 1894 the New Testament and during 1907 the complete Bible was published.

Northern-Sotho (Sepedi) - During 1890 the New Testament was published and in 1904 the complete Bible was published for the first time.

Venda (Tshivenda) - In 1920 the Gospels and the Book of Acts were first published, but during the period 1923 - 1925 the New Testament was finished and published. It took some years before the complete Bible was published during 1936.

Afrikaans - A different pattern has emerged with the Afrikaans Bible. In 1893 the first book, Genesis was published. In 1929 the Gospels with Psalms and four years later, in 1933, the complete Bible was published and distributed.

Swati (siSwati) - It was during 1976 that the Gospel of Mark was published and during 1977 a set of New Reader selections was published. The complete New Testament was published in 1980 while the complete Bible was only available in 1997.

Southern-Ndebele (isiNdebele) - During 1977 the Gospel of Mark and during 1987 the New Testament was published. In 1999 the translation of the Old Testament commenced. It will still take some years before the complete Bible will be published.

Notwithstanding the peculiar political dynamics in Southern Africa the Bible Society was also involved in translation and publication of the Bible in other languages other than those spoken in South Africa. One should never undervalue this work, but due to 
lack of space this work cannot be discussed and could justify an article.

\section{CONCLUSION}

Did the translation of the Bible into vernacular further the Mission cause? Did these "tools" bring the "results" and was all the money and time spent on the translation and eventual publication of the Bible in vernacular justified?

Barrett (1982:6) had the following to say on this issue:

"The role of vernacular translations of the Christian scripture in this growth of organised Christianity has been very marked. The Scriptures have motivated the planting of Christianity in Africa at every stage; they had directly caused its expansion in countless regions; they have produced the strong and mature churches which we now observe in most parts of the continent, and they nurtured them throughout".

I believe that without the written Word the Church and the Christian community would never have been as well established as it is currently throughout South Africa. This viewpoint could be debated and argued. David Livingstone wrote as far back as 1857: "Protestant missionaries of every denomination in South Africa all agree on one point, that no mere profession of Christianity is sufficient to entitle the converts to the Christian name. They are all anxious to place the Bible in the hands of the natives, and with the ability to read that, there can be little doubt as to the future" (Livingstone 1857:117-118).

As much as the Bible was intended to bring about stability something else also happened through the Bible. Sanneh (1989:188125) concludes that the Bible in vernacular has helped the people in Africa to dispense with colonialism, and to act independently from their former rulers. The development of a literary tradition in the different languages of Africa also helped them to believe in themselves.

This is what Gerdener (1958:241) has described half a century ago when he wrote the following:

"It is generally conceded that education of the heart as well as of the mind is an integral part of the task of

Christian Missions. Ignorance is the seed-bed of fear and 
superstition, while knowledge and enlightenment fosters the qualities of mind and heart which lead to selfdirecting and self-supporting Churches".

Education and the Bible have been "partners" from the beginning of mission activity in South Africa. The Bible is still being valued in most circles.

It is however disturbing to note that $19,3 \%$ of South Africans above 20 years of age have had no formal education. Another group of $16,7 \%$ have only had undergone primary training. This will inevitably lead to an insufficient reading ability. A conservative estimate is that over 7,5 million South Africans over the age of 20 are not able to read a Bible.

This leaves one with a clear impression that the work is not finished. The Bible Society will have to explore new and creative ways to bring the Word to the people. This they are currently doing in various ways. An important paradigm shift has indeed taken place, and in the process the non-readers are also receiving attention.

In conclusion it could be said that the Bible Society, the translators, and the partners in this ministry have all taken Mark 16:15 (CEV) seriously: "Then he told them: Go and preach (bring) the good news to everyone in the world".

\section{Consulted literature}

Barrett, D B 1982. The Spread of the Bible and the growth of the Church in Africa. UBS Bulletin 128/129, 1-25.

Bosch, D J 1991. Transforming Mission. Paradigm Shifts in Theology of Mission. New York: Orbis Books.

Chirgwin, A M 1954. The Bible in World Evangelism. New York: Friendship Press.

Gerdener, G B A 1958. Recent Developments in the South-African Mission Field. Cape Town: NG Kerk - Uitgewers.

Government Gazette of the Republic of South Africa, no 365 of 6 March 1970. Act No 15 of 1970. Pretoria, Government Printers.

Greenslade, S L (ed) 1963. The Cambridge History of The Bible. The West from the Reformation to the Present Day. London: Cambridge University Press.

Hermanson, E A 1999. A Brief Overview of Bible Translation in South Africa. Unpublished paper delivered at the Bible Translations Seminar of the University of Pretoria, 23-25 February 1999 at Hammanskraal. 
Kane, Herbert J 1975. The Making of a Missionary. Grand Rapids: Baker Book House.

Kane, Herbert J 1978. A Concise History of the Christian World Mission. A panoramic view of missions from Pentecost to the present. Grand Rapids: Baker Book House.

Livingstone, D 1857. Missionary Researches and Travels in South Africa. London: John Murray.

Neill, Stephen 1964. A History of Christian Missions. Aylesbury: Hazell Watson \& Viney Limited.

Sanneh, L 1989. Translating the Message. The missionary impact on culture. Maryknoll: Orbis Books.

Smit, A P 1970. God made it Grow. History of the Bible Society in Southern Africa, 1820 - 1970. Cape Town: Bible Society of South Africa.

Smith, N J 1980. Elkeen in sy eie taal. Pretoria: NG Kerkboekhandel.

Tolmie, D 1997. Church involvement in Bible Society work. Paper delivered at the Africa Assembly of the United Bible Societies, 15 September 1997, Midrand.

Van Engen, C 1996. Mission on the way. Issues in Mission Theology. Grand Rapids: Baker Book House.

Verkuyl, J 1978. Contemporary Missiology. An Introduction. Grand Rapids: William B Eerdmans Publishing House.

Walls, Andrew F 1996. The Missionary Movement in Christian History. Studies in the Transmission of Faith. New York: Orbis Books. 